\title{
doispontos:
}

\section{A quarta parede do marxismo francês: maio de 68 e a invenção dos dispositivos intelectuais de engajamento}

\author{
Nilton Ota \\ nilton.ota@gmail.com \\ Departamento de Filosofia, Universidade de São Paulo (USP), São Paulo, Brasil
}

Resumo: A crise da representação política que marcou as mobilizações contestatórias na França dos anos de 1960 e 1970 foi acompanhada pela invenção de modalidades de ação militante, em especial por aquelas integradas à produção cultural da primeira geração de intelectuais do pós-Segunda Guerra. A intensificação da crise afetou decisivamente o campo institucional do marxismo, conferindo um espaço privilegiado aos dispositivos intelectuais de engajamento soixante-huitards. Este artigo apresenta os resultados da pesquisa realizada nos arquivos de três desses dispositivos: o Groupe d'Information sur les Prisons (GIP), o Centre d'Études, de Recherches et de Formation Institutionnelles (CERFI) e a École Freudienne de Paris (EFP). Sob o crepúsculo do Partido Comunista Francês, trata-se da emergência de uma racionalidade crítica ao paradigma representacional, o qual passaria a ocupar, a partir de então, o imaginário político do marxismo antes hegemônico.

Palavras-chave: Representação política; Marxismo; Maio de 68; Intelectuais; Gauchismo; Engajamento.

\section{The 'fourth wall' of French Marxism: Soixante-huitard intellectual engagement devices}

\begin{abstract}
The crisis of political representation which marked the mobilizations in France in the 1960s and 1970s was accompanied by the invention of modalities of militant action, especially those integrated into the cultural production of the first generation of intellectuals of the post-war period. The intensification of the crisis decisively affected the institutional field of Marxism, giving a privileged space to soixante-huitard intellectual engagement devices. This paper presents the results of a research conducted on three of these devices: the Groupe d'Information sur les Prisons (GIP), the Centre d'Études et de Recherches de Formation Institutionnelles (CERFI), and the École Freudienne de Paris (EFP). In the twilight of the French Communist Party, it is the emergence of a critical rationality of the representational paradigm, which will occupy from now, the political imagination of what was once the hegemonic Marxism.
\end{abstract}

Keywords: Political representation; Marxism; May 1968; Intellectuals; Leftism; Engagement.

Por que os grupúsculos, em vez de comer uns aos outros, não se multiplicam ao infinito? A cada um seu grupúsculo! Em cada fábrica, cada rua, cada escola. Finalmente o reino dos comitês de base! Mas grupúsculos que aceitassem ser o que são no lugar em que são. E, se possível, uma multiplicidade de grupúsculos que tomariam o lugar das instituições da burguesia: a família, a escola, o sindicato, o clube de esportes etc. Grupúsculos que não temessem organizar-se, além de seus objetivos de luta revolucionária, para a sobrevivência material e moral de cada um de seus membros e de todos os desamparados que os cercam... (GUATTARI, 2004, p. 365)

Na condição de campo alternativo à orientação do Partido Comunista Francês, as formas de ação direta e as modalidades de engajamento soixante-huitardes conformaram um universo extenso e heterogêneo de práticas e discursos militantes, não à toa qualificados como integrantes do "gauchismo" do pós-segunda 
guerra. Até os anos 1960, a expressão serviria para nomear, seguindo a clássica significação leninista, as facções e correntes críticas à direção partidária. O "gauchismo" perderia essa carga pejorativa, passando a designar o campo militante não-alinhado ao PCF e o vetor organizacional que concentrava as iniciativas politicamente inventivas. Crítica à ortodoxia marxista e não ao marxismo em seu conjunto, portanto. A permeabilidade propiciada por essa conjuntura arejou o imaginário de grupos descontentes e então marginalizados dos debates pelas decisões tomadas nas altas instâncias do Partido, que controlavam os órgãos sindicais e as demais instituições de representação da classe operária. Muito de sua radicalização foi estimulada pelo insulamento ao qual foram destinados pela estratégia oficial de contenção do ímpeto revolucionário. A atmosfera política corroborava vivamente com a radicalização da militância marxista que ainda se mantinha fiel aos valores da revolução, não apenas à bolchevique, mas em especial ao espírito dos motins populares e anti-imperialistas que eclodiam em países longínquos e que correspondiam muito pouco ao "progressismo" professado pela cartilha do PCF. Tempos do "terceiro-mundismo" e, particularmente na França, das ideias da doutrina maoísta. As barricadas parisienses não convocaram ao acaso os fronts populares dos combates na China ou Vietnam, as guerrilhas nos países latino-americanos submetidos a ditaduras militares. Mais do que uma inspiração internacionalista, os levantes franceses manifestavam a adesão ininterrupta à derrogação social e política do paradigma representacional. Nos anos que precederam 68, as instituições e ideários comunistas detinham significativo prestígio cultural após anos de aparente concentração de forças políticas, ainda acolhiam os velhos traços da crítica ao reformismo, contudo foram incapazes de interpretar que, subjacente às usuais denúncias da contra-hegemonia partidária, ganhava corpo uma nova modalidade discursiva pronta a dar forma a um universo de práticas sociais, estas sim em acelerado processo de acumulação.

O meio estudantil foi claramente o primeiro espaço onde se desenvolveram e foram experimentadas essas práticas, mesmo que, da parte de seus participantes, não houvesse planejamento prévio de como cooptar seus efeitos e institucionalizar as afinidades estratégicas com outras modalidades críticas, gestadas em outros lugares e por atores políticos diversos. A orientação marxista permanecia ideologicamente forte, mas gradativamente divorciada da ação militante. Com a crise aberta pela guerra da Argélia, fenômeno similar ganhava terreno inclusive nas organizações historicamente obedientes à direção do PCF, como a Union des Étudiants Communistes (UEC):

Esse congresso pôde parecer como um dos mais "democráticos", senão como o "mais democrático" entre aqueles que a organização já havia conhecido. A batalha política não se situou sobre o terreno da confrontação entre escolhas estratégicas divergentes, e aqui o congresso perdeu todo seu caráter de congresso comunista. É importante constatar que nem a vontade dos "debates abertos" do antigo Diretório Nacional, suas tentativas para colocar previamente a toda discussão o respeito da democracia dos debates e da organização, nem mais o cuidado das formas que manifestou a maioria durante boa parte do VIII Congresso, os recuos táticos da tribuna, a "moderação" dos seus militantes muito exaltados não constituem a prova de que os debates foram realmente democráticos. Em uma organização comunista, o "liberalismo" formal dos debates não é de forma alguma o método de discussão dos congressos. Somente a confrontação das diferentes linhas propostas, a refutação das críticas teóricas e políticas, a resposta aos argumentos avançados são a característica dos debates comunistas. Esse não foi o caso, as oposições desenvolveram suas ideias em um vazio sem respostas. (...).

A igual recusa em discutir a linha que a esquerda defendia se inscreve nessa vontade de diálogo de surdos que foi aquela das maioriass. Poderia ser diferente em uma organização em que a linha da maioria, reclamando em tudo os princípios marxistas, os nega nos fatos? Uma política oportunista e reformista, fazendo nos congressos referência de modo religioso à teoria marxista que, além disso, ela própria esclerosa? (...)

Era importante para a maioria permitir a "todas as opiniões" se exprimir, uma vez que, em "se exprimindo livremente", a oposição lhe daria uma caução, lhe garantindo a pureza de suas intenções junto aos aliados que ela solicita. Não era menos importante para o antigo Diretório Nacional registrar constantemente o debate em torno da denúncia do caráter formal desse liberalismo, já que sua orientação consiste justamente em reclamar uma revisão livre da tática do Partido e a levar esta última a dar ganhos irrevogáveis aos seus aliados sociais-democratas, aos quais esse liberalismo gratuito não seria suficiente. ${ }^{1}$ 
O ataque ao "liberalismo formal dos debates", aos "recuos táticos da tribuna", à "referência religiosa à teoria marxista" pertence à forma canônica da verdade militante emancipada dos compromissos estabelecidos pela burocracia partidária. Por isso a conclamação da confrontação das "escolhas de estratégias divergentes", a negação da legitimidade automática das composições majoritárias, a defesa do verdadeiro terreno da "batalha política”. Ressalte-se: disposição crítica veiculada pelos canais de uma organização estudantil alinhada e subordinada ao PCF. A UEC não participaria dos motins no Quartier Latin e tampouco seria atirada ao centro dos eventos de maio (MAUPEOU-ABBOUD, 1974). Mais uma razão para sublinhar a natureza desse ataque e, sobretudo, de seu circunlóquio que, embora codificado pelo marxismo, insinuava algo significativamente diferente. A reiteração da crítica em torno do modo como se deram as discussões no congresso ocultava, mas não suprimia, a fonte real do descontentamento. A aclimatação sediciosa daqueles anos atingia até mesmo os territórios mais tradicionais do mundo comunista, permitindo a manifestação de segmentos militantes então silenciados pela unidade consensual garantida pelo respeito à hierarquia partidária. A despeito do desgaste de seu discurso, na UEC essa aclimação tomou a forma, tanto estranha quanto reveladora, de uma convocação protocolar da ação direta. Entretanto, a captura comunista da energia política disruptiva e socialmente represada enfrentava sérios obstáculos, agravados pela persistência, mesmo entre agrupamentos minoritários e avessos à ortodoxia partidária, das usuais táticas de comunicação doutrinária e alistamento militante. Foi assim que o aparato oposicionista pôde, concomitantemente, problematizar temáticas proibidas pelo PCF e enredar-se nos velhos dilemas sobre a mobilização das massas frente às injunções nacionalistas e suas alianças de classe durante a guerra de independência da Argélia. Como se sabe, a posição de neutralidade tomada pela direção do Partido em relação às lutas anticoloniais marcou a cisão definitiva no marxismo francês, selando o futuro de suas organizações no momento em que os acontecimentos de maio entrassem em cena. A reprodução das táticas partidárias pelos grupos oposicionistas os impedia de instituir novas práticas e, portanto, outras estratégias, justamente quando a conjuntura política fomentava fortemente medidas que escapassem ao enquadramento das ortodoxias, fossem elas liberais ou comunistas.

Apesar desse tipo de descompasso, entre os militantes das mais diferentes correntes oposicionistas ganhava acordo a crítica ao Estado, não apenas ao personificado pelo regime gaullista. $\mathrm{O}$ alvo tornara-se o Estado em si mesmo porque, ao contrário da defesa da "ditadura do proletariado", o pressuposto era autonomista e, assim, focado na questão da organização política, donde a "necessidade de uma efetiva descentralização da direção das lutas de massas em seus diversos níveis setoriais” (GUATTARI, 2004, p. 161), como declarava o documento apresentado, no mesmo congresso da UEC, pelo grupo do qual fazia parte Félix Guattari, a "Opposition de Gauche”. Entre suas "teses”, que contavam com o apoio de ex-trotskistas, figurava o reconhecimento das consequências da "atividade entrista subterrânea" e da "crítica abstrata", responsáveis pelo reforço ainda maior do “monopólio político do PCF no mundo operário” (IDEM, p. 160). O deslocamento sugerido por esse documento seria desdobrado, em diferentes frentes, pela elaboração teórica e clínica de Guattari. Por isso o valor estratégico atribuído pelo esquizoanalista aos engajamentos no "social”, face contemporânea do espaço de tratamento das ameaças à coesão da sociedade ${ }^{2}$, por excelência um campo fértil para a inventividade institucional. Se, como preconiza a "Opposition de Gauche", a "contradição fundamental do modo de produção capitalista" consiste na "contradição entre a estrutura econômica e a superestrutura de Estado que permite que aquela sobreviva”, e se a sua superação não pode prescindir da criação proletária das "próprias instituições", então, se compreende logo a função da “intervenção de uma subjetividade revolucionária cuja não-emergência histórica está na base da manutenção das instituições burguesas” (IBIDEM, 2004, p. 136). Em discurso e contextos eminentemente marxistas, constatava-se a mesma profissão de princípios, retirados das discussões nos grupos orientados pela Psicoterapia Institucional, matrizes dessa aplicação da "transversalidade" guattariana no âmbito das organizações comunistas (IBIDEM, 2004, p. 111). $\mathrm{O}$ passo seguinte será abandonar definitivamente o dogma da vanguarda revolucionária, nesse momento 
ainda arraigado até entre os militantes mais heterodoxos. ${ }^{3}$ Não sem razão que, nas discussões do grupo de redação das "teses" da "Opposition de Gauche", a menção ao valor estratégico da associação livre, "regra fundamental" da psicanálise, tenha sido acompanhada de reflexão a propósito de sua finalidade política de liberação das cristalizações significantes, de suas fixações pulsionais, presságio do que seria o estilo típico da ressonância militante da teoria fora das estruturas partidárias, no "gauchismo" em vias de expansão:

\begin{abstract}
O que é a regra fundamental? Ela não é essa redução que funda a verdade sobre a pessoa? É justamente o contrário. É para se assegurar que, em nenhum momento, ninguém irá se permitir cair nessa efusão. Isto quer dizer que ninguém aproveitará da prova significante para cair em um empreendimento de sedução, de parada, de miragem, na economia burguesa do imaginário, para que retornemos a todas essas relações. A regra fundamental intervém sempre no momento em que, no âmbito de um tipo de apercepção de fantasmas do grupo, se é levado a fazer uma requalificação dos fantasmas, de dizer isso: "é teu fantasma, desvencilhe-se". Mas não retemos do teu fantasma senão o que, para nós, é marcado, marcável, articulável no fantasma de grupo. ${ }^{4}$
\end{abstract}

Em pouco tempo, as ideias até então exclusivamente universitárias ou enclausuradas em ensinos quase esotéricos, como a formação psicanalítica, assumiriam as trilhas do mundo pelos atos iconoclastas de uma imaginação política em situação limítrofe. A dicção intelectual para uma movimentação fundada na ação direta, levada a efeito conjuntamente por distintas organizações políticas e grupos militantes, não foi um fenômeno que tenha surgido ao reboque dos protestos que marcaram o fim dos anos 1960 . O incremento e a transferência do prestígio e legitimidade da "produção ideológica" para o universo prático do "gauchismo", daquilo que a sociologia bourdieusiana definiu como "capital simbólico" (BOURDIEU, 1998), caracterizaram o "modelo de intervenção política dos intelectuais" da época (SAPIRO, 2009), o que pode explicar, ao menos parcialmente, o advento de dispositivos como, dentre outros, os instituídos por Michel Foucault, Jacques Lacan e Félix Guattari, respectivamente, o Groupe d'information sur les prisons (GIP), a École Freudienne de Paris (EFP) e o Centre d'études, de recherches et de formation institutionnelles (CERFI). A partir de 68, o "modelo profético do engajamento" passa a sofrer um acentuado declínio, atingindo em cheio os privilégios do intelectual que, autônomo em relação aos partidos ou a quaisquer organismos políticos, se punha a representar os interesses gerais, uma universalidade personificada e estilizada pelo seu carisma. A especialização resultante do fortalecimento das ciências humanas, somada à crescente divisão do trabalho e a prevalência do paradigma científico, condicionou o cenário em que o engajamento profético dos intelectuais veio a ser substituído pelo modelo que conciliava o saber localizado e a luta política concreta, estabelecidos mutualmente por limites estratégicos particulares, o "intelectual crítico especializado" ou, segundo seu nome foucaultiano de batismo, o "intelectual específico" (IDEM, 2009, p. 22-28). Daí a filosofia da diferença, embora avessa à teleologia dialética da história, ganhar repercussão no círculo acadêmico e, sem ajuste ou adaptação, encontrar afinidade de princípios junto a determinadas franjas da esquerda extraparlamentar. Porque essa filosofia, inicialmente deleuzeana e depois esquizoanalítica, era portadora de categorias que remetiam ao sentido dos engajamentos em curso, ela mostrava-se capaz de indexar, na sua própria linguagem conceitual, a disposição subjetiva de boa parte da militância "gauchista", o "fundo rebelde irredutivel" que permaneceria ativo sob as diferenças de toda representação política:

Como conceito de reflexão, a diferença testemunha sua plena submissão a todas as exigências da representação, que se torna, precisamente devido a ela, "representação orgânica". Consequentemente, no conceito de reflexão, a diferença mediadora e mediatizada submete-se de pleno direito à identidade do conceito, à oposição dos predicados, à analogia do juízo, à semelhança da percepção. Reencontra-se aqui o caráter necessariamente quadripartite da representação. A questão é saber se sob todos estes aspectos reflexivos, a diferença não perde, ao mesmo tempo, o seu conceito e a sua realidade. A diferença não cessa de ser um conceito reflexivo e não reencontra um conceito efetivamente real a não ser na medida em que designa catástrofes: sejam rupturas de continuidade na série das semelhanças, sejam falhas intransponíveis entre estruturas análogas. Ela não cessa de ser refletida a não ser para tornar-se catastrófica. E, sem dúvida, não pode ser uma coisa sem ser a outra. Mas, justamente, a diferença como catástrofe não testemunha um fundo rebelde irredutível que continua a agir sob o equilíbrio aparente da representação orgânica? (DELEUZE, 1977, p. 52) 
Do outro lado do espectro "gauchista", refratárias a esta figuração filosófica, as políticas da metáfora e seus radicalismos, encampadas pelos grupos maoístas e suas estratégias, ora com o recurso da força delitiva, ora por meio de uma elucubração discursiva, teorizante e distante de qualquer correspondência prática tangível. Maoísmo como metáfora política, certamente, mas não só. A mobilização subjetiva que o definia impunha um ato do militante contra si mesmo, uma depuração total da conduta ${ }^{5}$, donde a verdade manifesta através dos inúmeros testemunhos sobre o trabalho nas fábricas, dados por ex-établis: "Era tanto mais reeducativo quanto mais duro ele era" (DRESSEN, 1999, p. 177). A travessia de classe pressuposta na utopia inscrita no établissement não se concretizava pela simples aderência à rotina fabril, ainda que, em muitos casos, ela fosse reiterada ano após ano. $\mathrm{O}$ trabalho era o método e a depuração, o objetivo; expiação da classe pela subsunção do indivíduo às estruturas produtivas que determinam opressivamente a vida operária. O dispositivo maoísta não se confundia com o "entrismo" trotskista, já que se tratava, antes, de adentrar uma alteridade e não de combater um opositor. Na experiência dos établis, o opositor era o próprio militante, sua vida e história. A instituição do "novo homem" somente poderia ocorrer através da eliminação subjetiva do passado de classe incrustado nas entranhas do comportamento, das vontades, do pensamento; superar a dominação capitalista pelo ato sacrificial do indivíduo e seus antigos valores. Contudo, a profundidade das mudanças pregadas pela versão francesa da revolução cultural foi uma realidade para poucos, uma minoria abnegada e excessiva. Para o restante de seus militantes, o maoísmo oferecia gradações e exigências menos dramáticas, revelando ser uma opção política reversível, o que ele não foi em seu contexto de origem.

O decalque sociológico da ideologia maoísta não deve, no entanto, desacreditar a eficácia e significação políticas das práticas que compuseram a sua expressão militante. Configuradas inicialmente pela oposição às diretrizes do PCF, elas assumiram, a partir de 68 , uma dinâmica criticamente mais incisiva, a ponto de flertar com a utilização da violência, naqueles dias já com características do que anos depois viria a ser entendido como estratégia terrorista. Dois fatores sugerem ter sido decisivos para que a insurgência francesa não passasse ao ato da violência. O primeiro seria a politização do "social" e sua agenda ambígua entre a manutenção das medidas de proteção e a demanda crescente de autonomia individual. A contraposição política do "social" mostrava-se suficientemente forte para controlar a influência das vertentes mais radicais do marxismo. Em certa medida, o que os maoístas procuravam por intermédio do établissement, o "social" era relativamente bem-sucedido em proporcionar através do engajamento no trabalho junto a situações fronteiriças, com grupos segregados e invisíveis: os internos dos grandes hospitais psiquiátricos, os detentos prisionais, a ralé imigrante espoliada de direitos, os desfiliados de todo tipo. Obviamente, não seria possível contemplar as expectativas maoístas de depuração, mas no "social" a experiência lastreava-se em uma problematização que, concorde-se ou não com ela, encontrava de fato uma ressonância pública substantiva. Por isso a rápida convergência entre militantes "gauchistas" e trabalhadores sociais, entre formações acadêmicas e áreas disciplinares distintas em um campo prático cada vez mais profissional, estruturado experimentalmente e articulado a vários setores do Estado.

O segundo fator explicativo poderia ser observado na própria composição de classe dos grupos de extrema esquerda que assumiram a liderança nos debates e controvérsias, sem, contudo, manter o mesmo protagonismo nas fábricas e sindicatos (SOMMIER, 2008). Diferentemente do que aconteceria em outros países europeus ${ }^{6}$, os militantes extremistas eram provenientes das camadas mais escolarizadas da sociedade e raramente conciliavam, por imperativos materiais, os estudos com o trabalho. $\mathrm{O}$ hiato contra o qual os "gauchistas" se voltavam, desde maio de 68, consistia na dissociação entre os protestos nas universidades e as greves nas fábricas. A unificação das lutas era assim bloqueada em seu epicentro. A morfologia francesa da esquerda extraparlamentar refletirá integralmente os dilemas impostos por sua composição de classe. A se considerar essa dissociação, a invenção dos dispositivos intelectuais de engajamento constituiu um elemento fundamental da fisionomia do pensamento francês da década de 1970, estabilizando e dando 
superfície à integração entre os atores políticos e referências teóricas conflitantes no esteio de uma intensa movimentação social, instilando, ao final, uma espécie de espaço conjuntivo entre o sensível e o transcendental, a "experiência crucial" da diferença não representacional. Apesar de extravagante, não parece despropositado recorrer mais uma vez à significação alusiva da filosofia deleuzeana para qualificar a dimensão alvejada pelos dispositivos intelectuais, em disputa com outras instrumentações militantes:

\begin{abstract}
A diferença tem sua experiência crucial: cada vez que nos encontramos diante de ou numa limitação, diante de ou numa oposição, devemos perguntar o que tal situação supõe. Ela supõe uma abundância de diferenças, um pluralismo de diferenças livres, selvagens ou não domadas, um espaço e um tempo propriamente diferenciais, originais, que persistem através das simplificações do limite e da oposição. Para que as oposições de forças ou as limitações de formas se desenhem, é preciso, antes de tudo, um elemento real mais profundo que se defina e se determine como uma multiplicidade informal e potencial. (DELEUZE, 1977, p. 71)
\end{abstract}

Certamente, o maoísmo francês pôde reconhecer o sinal de época das especulações filosóficas da diferença no mesmo instante que refutava o caráter ideológico de seu eloquente ataque à dialética. $\mathrm{O}$ ideário da revolução cultural não apenas nutria-se de um anti-intelectualismo puro, como também configurava um regime discursivo que abolia por completo a distinção entre o movimento do conceito e sua passagem ao ato. Se a filosofia da diferença fosse levada a cabo pelos maoístas, o "simulacro", como "signo" que "interioriza as condições de sua própria repetição", seria praticado, não ao modo formal da poética vanguardista de Mallarmé ou Joyce (IDEM, p. 94), mas de acordo com a reta obediência aos preceitos da "autocrítica" militante. Daí a anulação da individualidade do pensamento, a defesa do anonimato e espontaneidade das massas, formadas no trabalho real e, portanto, sem as distorções causadas pelas abstrações do raciocínio estéril e falsificado dos intelectuais. A economia das práticas que regravam a conduta maoísta era, por definição, ritualística. Sua produtividade normativa incidia sobre o comportamento, todavia não para disciplinar seus gestos com vistas à extração da utilidade exigida pelos aparelhos de poder. Não havia senão uma circularidade procedural vazia nos seus mecanismos depurativos, bem mais arraigada do que fazia crer a "autocrítica". Circularidade, vale dizer, que garantia algo simetricamente oposto ao que era destinado classicamente ao intelectual do PCF. Ao contrário deste, que se valia da função de servir de "apoio à estrutura afetiva [do PCF] para reforçar a confiança dos aderentes" (ANSART, 1983, p. 118), o établi projetava a convicção militante no núcleo da alienação subjetiva instituída materialmente pela atividade laboral. A depuração era, portanto, real, mas sob a condição de ser subjetivada tão-somente pelo vazio ritualístico da práxis maoísta.

A prerrogativa francesa do maoísmo era tanto mais contraditória quanto mais radicalizado procurava ser o discurso militante. Isso talvez possa explicar o fato do marxismo althusseriano ter fornecido alguns dos maoístas mais influentes, que ocupariam com liderança os inúmeros espaços abertos pelo "gauchismo" após 68. Mas apesar de seus discípulos maoístas, o que lhe renderia acusações veladas, feitas pela direção do PCF, de ser um "pro-chinois", ou seja, um revisionista (MATONTI, 2009), Althusser jamais reconheceu publicamente a revolução cultural como referência política a ser defendida ou associou sua filosofia à doutrina de Mao. ${ }^{7}$ Essas desconfianças e acusações refletiam, na verdade, as mudanças pelas quais passava o PCF, em especial o impacto da política de alianças de classe conduzida pela cúpula e, consequentemente, a necessária renovação teórica a partir de uma leitura humanista dos textos de Marx. Essa orientação reconciliadora foi objeto de ataques frontais, entre os quais o de Foucault que, apesar de suas profundas divergências com Althusser, perfilou-se ao seu lado e de outros antagonistas na mesma trincheira contra a tentativa diversionista do humanismo propalado pelo PCF (FOUCAULT, 2001, p. 686). A generalização das premissas estruturalistas na década de 1960 encontra nesse combate a sua função estratégica.

A politização do estruturalismo deve ser compreendida no contexto de reposicionamento do PCF, sendo a partir dele que se torna possível explicar melhor a guinada althusseriana à extrema esquerda. Integrando Marx ao estruturalismo, sua leitura "sintomal" deslocaria os problemas sobre a linguagem para 
uma abordagem propriamente política (MATONTI, 2005). Mas de maneira alguma esse deslocamento e seus efeitos se restringiam à filosofia de Althusser. Inexistente e impensável para os fundadores do primado da sincronia, a face "gauchista" do estruturalismo resulta diretamente de sua exacerbação política. Daí a conjunção teórica entre as regras da linguagem e a ordem das determinações materiais da história, a produção econômica da sociedade e a funcionalidade estrutural do simbólico. A disseminação desse genuíno oximoro político, sob a forma híbrida dos conceitos, deu moldura ao declínio do PCF e a definitiva inscrição dos problemas da esquerda extraparlamentar na esfera de legitimação cultural do pensamento francês, sendo prova desse processo a massificação dos coletivos militantes recém-criados e desprovidos de recursos políticos tradicionais, imprescindíveis para a disputa de posições no conturbado e movediço cenário institucional da época. Por mais paradoxal que hoje possa parecer, a essa politização também deve ser atribuída a crise que rapidamente assolou o estruturalismo, convertendo em ideologia o que era um promissor paradigma científico e um campo intelectual crítico. O recuo do primado da sincronia obrigava os seus antigos próceres a medidas de readequação em um terreno cada vez mais pautado pelas demandas da nova geração universitária, já batizada pelos motins do final dos anos 1960.

Caracterizava uma das principais preocupações políticas dos intelectuais críticos se aproximar, intervir e capturar, no âmbito mesmo de suas obras, a crescente força social da juventude escolarizada, fruto de décadas de expansão do sistema de ensino. Mais uma vez, Althusser sinalizaria com clareza os bloqueios e as variações típicas dessa empreitada intelectual, certamente arriscada e na qual inúmeros de seus contemporâneos sucumbiriam diante das insurgências e da conflitualidade cíclicas existentes na formação desse novo campo político. Ao propor conceitos ajustados à conjuntura dominada pelas práticas contestatórias do "gauchismo", a exemplo dos "aparelhos ideológicos do Estado", ou ao definir as coordenadas de uma "luta de classes na teoria", Althusser teria procurado traduzir sua posição "marginal" e "heterodoxa" no PCF em uma interlocução abrangente com os grupos de extrema esquerda, mediada pelos conceitos e pela sua forte influência sobre o maoísmo normalien (MATONTI, 2009, p.126). Atitude completamente diferente daquela adotada até o biênio 1964-65, momento de inflexão, não sem motivo, acompanhado tanto pelo início de sua relação com Lacan, cujo seminário receberia teto, com o seu apoio, na École Normale Supérieure, quanto pelo ciclo de discussões que desembocaria na redação coletiva de Lire Le Capital, com a participação de alguns dos seus alunos maoístas (RANCIERE, 2012). Mudança abrupta e segundo o ritmo acelerado daqueles dias. Apenas um ano antes, Althusser mantivera guarda contra a investida do que acreditava ser a ideologia pequeno-burguesa sob o disfarce do engajamento estudantil, chegando a publicar, em 1963, um artigo a respeito (ALTHUSSER, 1964). E tão logo concluíra pelo declínio da hegemonia estruturalista, proporia, em 68 , um curso de filosofia para cientistas, iniciativa inusitada vindo de um intelectual como ele. A inspiração não teria somente caráter educativo. Tratava-se novamente de restabelecer a "luta de classes na teoria", agora representada pela polarização entre filósofos, tendencialmente idealistas, e cientistas, espontaneamente materialistas. ${ }^{9}$

Os princípios que nortearam esse curso foram descritos, retrabalhados e sistematizados em $1976 .{ }^{10}$ Nessa versão, preparada sob o clima do arrefecimento paulatino da capacidade de combate dos grupos da extrema esquerda francesa, Althusser propõe, de acordo com seu modo peculiar de produzir inversões, a hipótese de um núcleo idealista em Gramsci, uma certa "prática de abstração" que não faria senão reproduzir a tendência imanente da posição da filosofia na luta de classes, noção já professada na edição original do curso. Essa inversão permitiria a Althusser apresentar o conceito de "modos de abstração" como fio condutor da análise, identificando a pluralidade prática implícita até mesmo na totalização vislumbrada pela práxis gramsciana. Assim, a "abstração" teria se transformado em uma espécie de "excesso do pensamento sobre toda instância teórica" (SIBERTIN-BLANC, 2014, p. 16), donde a distinção entre teoria e prática somente continuar a fazer sentido nos contextos de hierarquização litigiosa dos saberes. Como em Foucault, essa 
concepção corresponderia a uma crescente preocupação em sublinhar o enraizamento político da Filosofia. Aqui, percebe-se com relativa facilidade que a filosofia se sobrepõe à ideologia, o que, para Althusser, explicaria a crise do marxismo. A problemática sobre os "aparelhos ideológicos de Estado" ganha nova configuração, sendo reforçada pela "tópica das práticas" e seus "regimes de abstração", que auxiliam a interpretação althusseriana no registro da "multiplicidade ideológica" (IDEM, p. 22), nova gravitação teórica da luta de classes. A radicalidade desse projeto envolveria a filosofia ela mesma. Por isso o imperativo althusseriano de uma "nova prática da filosofia" como condição para a instituição da "nova filosofia" (IBIDEM, p. 26) e, talvez, a justificativa para outra conversão, a da militância dos filósofos, transformados, segundo as próprias palavras do autor de Pour Marx, porque eles saberiam que sua "filosofia lhes chegará de fora" (ALTHUSSER, 1998):

Talvez pela primeira vez em sua história o marxismo esteja à véspera de profundas mudanças, cujos primeiros signos são visíveis. A teoria marxista pode e deve hoje tomar por sua conta, para não mais abandoná-la, a velha palavra de Marx: nós devemos "acertar as contas com a nossa consciência filosófica anterior". E antes de tudo com a "consciência filosófica" de Marx, sempre "anterior". Sabendo que não é um assunto dos solitários filósofos, intelectuais e dirigentes, nem mesmo o assunto dos partidos isolados, já que "todo homem é filósofo" (Gramsci). É em última instância o assunto das massas populares à prova de seu combate. (IDEM, p. 308-309)

\title{
OS DISPOSITIVOS INTELECTUAIS DE ENGAJAMENTO E SEUS VETORES ESTRATÉGICOS
}

\begin{abstract}
M. Foucault: Um maoísta me dizia: 'Eu compreendo porque Sartre está conosco, porque e em que sentido se faz política; você, eu compreendo um pouco; você sempre colocou o problema da reclusão. Mas Deleuze, realmente eu não compreendo'. Esta observação me surpreendeu muito porque isto me parece bastante claro.

G. Deleuze: Talvez seja porque estejamos vivendo de maneira nova as relações teoria-prática. Às vezes se concebia a prática como uma aplicação da teoria, como uma consequência; às vezes, ao contrário, como devendo inspirar a teoria, como sendo ela própria criadora com relação a uma forma futura de teoria. De qualquer modo, se concebiam relações como um processo de totalização, em um sentido ou em um outro. Talvez para nós a questão se coloque de outra maneira. As relações teoria-prática são muito mais parciais e fragmentárias. Por um lado, uma teoria é sempre local, relativa a um pequeno domínio, mais ou menos afastado. A relação de aplicação nunca é de semelhança. Por outro lado, desde que sua teoria penetre em seu próprio domínio encontra obstáculos que tornam necessário que seja revezada por outro tipo de discurso (é este outro tipo que permite eventualmente passar a um domínio diferente). A prática é um conjunto de revezamento de uma teoria a outra e a teoria um revezamento de uma prática a outra. Nenhuma teoria pode se desenvolver sem encontrar uma espécie de muro e é preciso a prática para atravessar o muro. (FOUCAULT, 1996, p. 69)
\end{abstract}

O trecho em epígrafe dispensa maiores apresentações. A transcrição desse encontro, ocorrido em 1972, entre dois dos principais filósofos da geração que sucedeu à de Sartre talvez seja um dos mais reproduzidos para ilustrar a aclimatação de época, na qual a figura do intelectual engajado passou a ganhar fisionomia pública pelo estilo de intervenção prática glosado em sua teoria. Engajamento intelectual atrelado a um curso concreto dos eventos, à "brecha" do poder (MORIN; LEFORT; CASTORIADIS, 2008) que se manifestava onde fosse possível, nas ruas, universidades, fábricas, instituições de saúde, espaços culturais (DAMAMME, 2008). Certamente, momento filosófico heterogêneo e passível de ser segmentado em áreas classificáveis conforme os critérios da especialização universitária. Contudo, momento resistente a classificações rígidas porque constelado por singularidades filosóficas cruzadas e interdependentes a outros momentos, estes também político, epistemológico e estético (MANIGLIER, 2011). É nesse contexto que as relações entre teoria e prática foram instrumentalizadas e puderam ser compreendidas como "revezamento", processo de uma alteridade que atravessa as parcialidades regionais do pensamento e da ação em um movimento sem totalização. A atualidade dessa configuração intelectual e a extensão da influência das instrumentalizações correspondentes sobre as modalidades de ação política e de mobilização social nos últimos quarenta anos permanecem questões em aberto, para as quais nenhuma resposta pode ser dada sem que antes se compreenda 
as problematizações que ordenavam os ideários e as disposições práticas, que significavam motivações e as inscreviam em condutas de militância. A história dessas problematizações sedimentou-se nas teorias e nos discursos da época, mas também na memória organizacional dos coletivos que surgiram a partir do engendrar desse novo engajamento. Daí a importância dos dispositivos intelectuais de engajamento, instrumentações da nova relação entre teoria e prática inaugurada na segunda metade dos anos de 1960. Multifacetado, o processo de constituição desses dispositivos se fundamentou ideologicamente por intermédio de formas de contestação que prescindiam das antigas instituições de representação política.

Nesse aspecto, o modelo autonomista ocupava o centro do imaginário utópico de 68 , contudo com desdobramentos inicialmente imprevistos. É o que sugere a bibliografia sobre a radicalização política dos anos 1970 (KATSIAFICAS, 2006; SCHNAPP \& VIDAL-NAQUET, 1988; SOMMIER, 2008). Observável em diversos países, o fenômeno de organização de grupos de guerrilha urbana, longe de ser um episódio descontínuo à ampla mobilização social da segunda metade da década de 1960, exprimia com ainda mais intensidade a forte crise de legitimação pela qual passavam as principais democracias na Europa. Ao mesmo tempo, outra esfera crítica problematizava à sua maneira a crise de legitimação do Estado liberal. Em particular na França, o campo de assistência e proteção sociais passou a congregar duas temporalidades históricas distintas e em confronto. A interpretação da crise pela matriz republicana da “questão social” (DONZELOT, 1994; EWALD, 1984; PROCACCI, 1999; CASTEL, 1999) levava a uma compreensão convencional do sentido político dos acontecimentos desencadeados pelos motins de 68 . Por sua vez, esse mesmo campo prático assimilou os valores de autonomização do sujeito, se aproximando, no âmbito prático das rotinas de trabalho, do modelo político da ação direta, hegemônico entre os grupos de extrema esquerda.

A produção recente sobre maio de 68 tem fornecido importantes elementos a respeito da formação ideológica e da história organizacional dos grupos de militância que, em dissidência ou em rompimento com o Partido Comunista Francês, engrossaram as fileiras dos amotinados em seus diferentes espaços, cada qual impactado com a afluência de um público altamente politizado, mas à deriva das instituições de representação de classe e à procura de novas experimentações coletivas. Os dispositivos intelectuais de engajamento não se colocaram à parte dessa movimentação. Pelo contrário. Eles foram resultado e, em determinados aspectos, constituíram um posto avançado das formulações programáticas e, sobretudo, da integração entre intelectuais e grupos de extrema esquerda que culminaria, na década de 1970, com a hegemonia do modelo político de ação direta, adotado, inclusive, pelas facções de inspiração marxista na Itália e Alemanha (SOMMIER, 2008; LE GOFF, 2006; WOLIN, 2010; SMITH \& MONCOURT, 2009). Por outro lado, esses dispositivos também foram determinantes na fixação de militantes em instituições pré-existentes, notadamente nas de saúde mental, já tocadas pelas correntes da antipsiquiatria, e em muitos setores da estrutura de serviços públicos (GUATTARI, 2004; 2012; MOZÈRE, 1992; ROUDINESCO, 1986; DAMAMME, 2008). Ao contrário do sistema eletivo de representação política, fragilizado pelas novas modalidades contestatórias de ação e organização coletivas, o "social” foi atravessado pela recomposição das forças de mobilização militante, lhes fornecendo um terreno prático de experimentações sem igual na história recente das principais democracias liberais da Europa, no qual a eclosão dos levantes de maio de 68 encontrou bases estratégicas em grande medida prefiguradas.

Essa via de confluência estratégica teve por consequência um conjunto de traduções de problemas antes assimilados pelas práticas reformistas do "social" e pelas instituições de representação política ou de classes. Questionadas pelo processo difuso e abrangente de contestação, formas de pactuação democrática do Estado Providência tornaram-se obsoletas em um espaço surpreendentemente curto de tempo. É esse sentido disruptivo, concorde-se ou não com ele, que divide as interpretações sobre maio de 68 , tanto 
aquelas que lhes são contemporâneas, quanto outras, elaboradas ao longo dos últimos quarenta e cinco anos. O exame da bibliografia e a análise da documentação disponível sobre o GIP, CERFI e EFP, três dos principais dispositivos intelectuais de engajamento da época, permitiram identificar vetores estratégicos, em grande parte responsáveis pela estruturação do campo e da morfologia da experiência militante e de suas problematizações: a politização da subjetividade, o modelo organizacional da ação direta e a regionalização de uma totalidade metafísica do poder.

\section{A POLITIZAÇÃO DA SUBJETIVIDADE}

À prova dos valores de defesa da autonomia da subjetividade, incitados pela eclosão de novos sujeitos e suas formas inusitadas de ação política, os militantes vivenciavam uma contradição insolúvel. Seu engajamento passava por essa contradição e, nos dispositivos investigados, foi objeto de modalidades organizacionais de potencialização ou amenização dos efeitos acarretados pelo fato da exacerbação subjetiva dos militantes conviver e se apoiar em ideários de inspiração revolucionária. Embora revigorado pelas novas formas políticas, o imaginário da revolução socialista envolvia fortes imperativos de contração da individualidade militante, no momento em que ela dispunha, na esfera da cultura, de repertórios e condições para tornar-se mais expressiva e performática. O vetor estratégico modulado a partir dessa incongruência foi a politização da subjetividade, imprescindível para se compreender a eficácia dos dispositivos e seu potencial de expansão. Entre as injunções que mobilizavam a sublevação de 68, a idealização da autonomia individual evocada, paradoxalmente, no contexto da defesa do "social" era, certamente, a que melhor representava a tensão contida nessa politização. Portadores das contradições fundadoras do republicanismo francês, os insurretos de maio ergueram barricadas em nome dessa autonomia por meio do "discurso da mudança" da sociedade e das próprias vidas, antes de se engajarem, com a mesma tenacidade, "na realização de si e de se tornarem os melhores missionários da autonomização do social” (DONZELOT, 1994, p. 247). ${ }^{11}$

Uma das variações mais significativas do campo de problemas instituído pela politização da subjetividade ganhou realidade anos mais tarde com o declínio das paixões revolucionárias, a "crise do engajamento" da segunda metade da década de 1970, quando já não se tratava mais das contradições da militância, mas de responsabilização construída e tematizada pelo mercado editorial dos testemunhos de ex-maoístas franceses que, sob o "efeito Soljénitsyne", pontificavam a resistência aos riscos expostos por todas as ideologias de esquerda (LE GOFF, 2006, p. 447). Essa responsabilização "anti-totalitária" constituía uma espécie de confissão coletiva de culpa, todavia somente autorizada aos ex-militantes que haviam sido capturados pela invocação revolucionária e que, portanto, poderiam dar testemunho de sua força e ilusão. Na versão produzida pelos nouveaux philosophes, a politização da subjetividade transformou-se, assim, em vigilância e controle, apresentadas como partes integrantes de uma ética de combate contra todos os totalitarismos. Tradução lesiva do legado de 68, na medida em que sua "lógica de culpabilização total" "interdita aceitar a ambivalência de nossa história e bloqueia toda reconciliação com a parte positiva de nossa tradição" (IDEM, p. 411). Mais ainda: em sua constante procura por indícios de "novos fascismos", de totalitarismos latentes, os nouveaux philosophes distorceram os dilemas da subjetividade militante, equiparando as experiências da França da década de 1960 com as da China sob a revolução cultural ou do regime stalinista.

Como têm destacado os estudos comparativos de Sommier sobre a radicalização política de grupos esquerdistas nos anos de 1970, a configuração militante na França seria oposta da italiana - ao lado da alemã, a experiência europeia mais extrema -, esta muito mais assentada em uma aliança progressiva e duradoura entre intelectuais e a classe trabalhadora do que aquela, cujos "círculos de militância" teriam sido "artificialmente" mantidos e cuja profusão de "declarações triunfalistas" já denunciava seu "processo de construção mítica" (SOMMIER, 2008, p. 126). A radicalização dos grupos militantes na França possuiria um claro corte de 
classe. Formados, majoritariamente sob a liderança de alunos das grandes e prestigiadas escolas parisienses, esses grupos teriam transitado, a partir de 67, de uma militância altamente intelectualizada para outra, de "abnegação" irrefletida. Nesse percurso, injunções ambivalentes marcariam a expressão da subjetividade de seus integrantes. Pressionados entre os valores de ascensão social e os da nova identidade adquirida pela política, os militantes de origem popular ou pequeno-burguesa, que haviam alcançado as melhores instituições de ensino, estariam, ainda segundo Sommier, em posição de padecer do que Gaulejac (1987) chamou de "neurose de classe". A movimentação política intensa teria oferecido suporte para que uma justificativa sobre a nova posição social pudesse ser articulada, de modo conciliatório, à origem familiar e seus imperativos de classe. Por sua vez, ao contrário do sofrimento de seus companheiros "trânsfugas de classe", o sentimento permanente, vivido pelos militantes de procedência burguesa, de uma "dívida imaginária" 12 com o proletariado não encontrava vazão nesse tipo de conciliação, o que, provavelmente, corrobora a percepção de que a renúncia intelectual e o sectarismo fossem ainda mais fortes entre eles.

A dissociação entre as correntes estudantil e operária nas principais movimentações de 68 refletia um conteúdo classista das formas de contestação, embora existissem afinidades e, em algumas circunstâncias, aproximações reais entre estudantes e operários. ${ }^{13}$ De acordo com esse tipo de interpretação sociológica, os traços revolucionários presentes na conformação francesa do engajamento político despojavam-se de base material, tendo muito mais um sentido metafórico, com eficácia performática, do que uma natureza prática de classe. ${ }^{14} \mathrm{~A}$ despeito de um certo reducionismo que possa de fato carregar, esse diagnóstico localiza com precisão o centro de gravidade das contradições inscritas na experiência subjetiva da militância. Até mesmo estudos que não se alinham teoricamente a esse tipo de interpretação reconhecem a nucleação classista da subjetividade mobilizada pelo engajamento, fonte também do padecimento ou liquidação psíquica de ex-militantes de grupos de extrema esquerda, com o crepúsculo do período de incitação das paixões revolucionárias. Uma vasta literatura de testemunhos, muito mais abrangente do que a seleta editorial dos nouveaux philosophes ${ }^{15}$ e sua tônica culpabilizante, registra esse fenômeno com tonalidades que revelam, de um lado, diferenças significativas em relação ao estilo narrativo e, de outro, acentuadas afinidades entre os efeitos subjetivos envolvidos nas trajetórias que levaram do engajamento intelectualizado à radicalização, terminando na negação completa ou na reavaliação da experiência (CHRISTOFFERSON, 2004; MANDOUÉ, 2009; LE GOFF, 2006; WOLIN, 2010).

A experiência militante, vista do ângulo da subjetividade, também constituía uma questão de fundamental importância no interior das dinâmicas coletivas dos dispositivos intelectuais. No CERFI, a dimensão subjetiva da militância recebeu atenção prioritária, diversamente do que havia ocorrido no GIP e na EFP, onde ela foi tomada a partir de suas consequências políticas, o que significava defender uma necessidade de assimilação quase terapêutica, como podemos observar na escola lacaniana, ou, no grupo liderado por Foucault, de objetivação projetiva no "outro", representado pelo detento da prisão, cuja vida era preciso tornar visível pela incitação da sua própria fala. Ao mesmo tempo no lugar de objeto de intervenção e na condição de temática de investigação e ação política, a subjetividade militante constituiu o principal vetor estratégico do CERFI. As linhas de estruturação desse vetor são, basicamente, as mesmas que demarcaram o horizonte de expectativas dos grupos de esquerda na França das décadas de 1960 e 70. Contudo, no CERFI, ele foi responsável pela emergência de um conhecimento particular sobre a subjetividade militante, um saber especificamente vinculado à problematização da atualidade do poder. Certamente, o mesmo pode ser observado nas obras esquizoanalíticas redigidas em conjunto por Deleuze e Guattari, seus próceres. Mas há uma diferença substancial, em relação a qual não há medida comum de comparação. Nos dispositivos intelectuais de engajamento, trata-se de uma objetivação organizacional da relação entre teoria e prática, ausente ou apenas tematizada nas obras de Foucault, Guattari e Lacan. Uma diferença de estatuto epistemológico marca a distância entre esses saberes. Para identificar e compreender a teoria criada 
por esses dispositivos, não é suficiente analisar sua produção ao modo de uma exegese de texto. O saber dos dispositivos se expressa na própria dimensão da objetivação organizacional e ganha materialidade pela convergência entre as estratégias internas e as que atravessam os grupos, sedimentadas e retrospectivamente ordenadas por princípios de gestão das práticas e condutas militantes. Em especial no que tange ao CERFI, a objetivação organizacional se dava pelas práticas coletivas de circulação do discurso e pelos posicionamentos subjetivos que se declaravam nessa dinâmica. Embora o recurso a sessões de esquizoanálise tivesse sido adotado na gestão do coletivo (FOURQUET, 1982; DOSSE, 2007), foram as modalidades de engajamento repertoriadas e transformadas no curso do trabalho do CERFI que configuraram um saber próprio sobre a subjetividade militante, feito não alcançado nem pelo GIP, nem pela EFP, estes, no entanto, responsáveis por outras invenções. ${ }^{16}$

\section{O MODELO ORGANIZACIONAL DA AÇÃO DIRETA}

A tradição autonomista, com suas diversas ramificações, é muito anterior ao advento dos dispositivos estudados. Ela própria remonta ao cruzamento de dois campos diferentes, o anarquismo e o socialismo, cada qual com suas correntes próprias. O legado histórico dos autonomistas é tão difícil de ser analisado quanto a "herança de 68 ". Contudo, se nos ativermos na continuidade de alguns de seus traços, o problema da autonomia no trabalho como meio de emancipação ganha atualidade pela militância de 68 , em especial através de seu modelo organizacional de ação direta. ${ }^{17} \mathrm{Na}$ hibridação de traços de outras tradições políticas, a questão da ação direta foi idealizada no interior dos grupos militantes (DEBORD, 1995) e, de fato, alçada a princípio central do modelo organizacional dos dispositivos intelectuais de engajamento. É provável que essa hibridação seja uma das prerrogativas da forma política soixante-huitarde e, portanto, uma das razões que explicam a dificuldade em interpretá-la. Seu movimento constante de paráfrases e evocações históricas extremamente distantes desenvolve um mosaico discursivo altamente volátil. Antes de desqualificá-la como simplesmente uma espécie de antessala do capitalismo avançado (VANDENBERGHE, 2008), tal forma política exige, primeiramente, uma análise que retenha os traços em sua pertinência histórica, identificando, em um segundo tempo, o deslizamento semântico realizado. É assim que a Revolução Cultural chinesa, assimilada por grupos de extrema esquerda, pode ser lida como uma metáfora. $O$ maoísmo francês manteve o anti-intelectualismo original, mas despojava-se de qualquer referência a um espaço laboral intensivo, tópico fundamental na economia imaginária que definia a ideologia chinesa. Ao invés disso, tinha uma injunção sectária que, desde o seu início, já revelava uma tendência subjetivante. Não à toa que tenham vindo de ex-maoístas, particularmente de ex-alunos da École Normale Supérieure, a impostação de um discurso culpabilizante, logo revertido em fenômeno editorial de massa. Foi entre militantes maoístas que a EFP encontrou seus melhores quadros no seu esforço de renovação do lacanismo, naquele tempo fragilizado no movimento internacional da psicanálise.

A fundação da EFP introduziu mecanismos inéditos de certificação psicanalítica, dos quais o "passe" foi, sem dúvida, o mais polêmico e funcional aos propósitos de aumentar a permeabilidade do lacanismo à aclimatação política da época. $\mathrm{O}$ "passe" configurava o modo institucional de reconhecimento do psicanalista, este levado a colocar em público sua relação com o inconsciente. Diante de seus pares, mas sem a hierarquia que tanto identificava as tradicionais escolas freudianas, o candidato a membro da EFP deveria se submeter a esse processo que, por sua vez, correspondia a uma inusitada subversão organizacional. Em sua função na instituição lacaniana, o "passe" designava a garantia de que a passagem do candidato a membro da Escola sustentava-se sobre a elaboração da história de seu tratamento psicanalítico, exposta a uma comissão, cuja atribuição seria de avaliar e dar reconhecimento à enunciação de um analista através dos relatos dados. Talvez seja possível ver no "passe" uma formulação que procurava responder aos imperativos subjetivos dos jovens lacanianos. Como muitos militantes de sua geração, esses jovens pertenciam a grupos de extrema esquerda, 
todavia não mantinham a disposição de levar o seu radicalismo político às últimas consequências, o que os colocava diante dos impasses gerados pelo ideal da subjetividade revolucionária que, no limite, acarretava “a aceitação da morte possível, a sua e a dos outros" (LE GOFF, 2006, p. 408). É neste ponto que o "passe” revelou-se a versão lacaniana do modelo político da ação direta. Nele, a "transferência com o inconsciente"18, atributo primaz de um analista, não exige qualquer representação ou delegação. O saber que ratificaria um analista seria o mesmo da ordem do saber inconsciente. Daí a noção de que a intervenção analítica seria, antes de qualquer coisa, um "ato" (LACAN, 1999; 2008), ação direta de incidência no inconsciente; uma ética, portanto. Muito mais do que uma simples certificação institucional, o "passe" correspondia a uma forma precisa de interlocução com essa constelação ideativa da intensificação política da segunda metade da década de 1960. Inscrita no engajamento da nova geração de lacanianos, essa constelação tornava-se alvo da EFP. Pela primeira vez, uma instituição de psicanálise não apenas mostrava-se deliberadamente aberta aos não-psicanalistas e à política de seu tempo, mas igualmente lhes reservava o lugar de centro (ROUDINESCO, 1986).

A história da aproximação entre o lacanismo e os jovens insurretos possui duas dimensões, uma doutrinária, outra política. A primeira consiste nas transformações do lacanismo no bojo das correntes teóricas nacionais que compunham o movimento internacional da psicanálise. A outra se constitui pela dinâmica política à qual o lacanismo foi incorporado no processo de interação com outras esferas da sociedade. $\mathrm{O}$ encontro entre essas duas dimensões se cristalizou na EFP, dando realidade a uma terceira dimensão, a do discurso teórico eticamente motivado. É nessa dimensão que a ação direta como modelo organizacional teve, na EFP, uma centralidade ausente no GIP e até mesmo no CERFI e sua conhecida inspiração na experiência iugoslava dos conselhos de trabalhadores. Paradoxalmente, em uma das instituições mais teorizantes e cuja certidão intelectual de nascimento remontava à aversão freudiana à massificação da psicanálise, o modelo político da ação direta foi codificado e revertido em ética, um projeto anunciado por Lacan na década de $1950^{19}$, mas somente materializado com a EFP. A tese da psicanálise como uma ética foi extensamente conceitualizada por Lacan, em um intervalo de mais de vinte anos, que se inicia em 1954 e vai até 1981, ano de sua morte, permanecendo, mesmo nos dias de hoje, no posto de princípio-base de todo o campo lacaniano, independentemente de sua divisão interna em correntes interpretativas. Se muitas das formulações teóricas de Lacan foram objeto de disputas entre seus discípulos, no que diz respeito ao universo prático chancelado pela etificação da psicanálise, os conflitos cessam e o consenso ganha feições de doutrina, não tendo como referência apenas a estabilidade alcançada pela interpretação teórica, mas, sobretudo, a história de um dispositivo eficaz tanto em incitar quanto em controlar o engajamento político. ${ }^{20}$ Foi nesse sentido que a EFP pode reconstituir o processo que transformou a ação direta em princípio estratégico de conversão da teoria lacaniana em prática de um discurso eticamente motivado, o que, com o tempo, será uma das mais vigorosas modalidades de expansão dos preceitos clínicos antes confinados ao setting do psicanalista.

\section{A REGIONALIZAÇÃO DE UMA TOTALIDADE METAFÍSICA DO PODER}

É fato conhecido a inicial distância mantida por Foucault em relação ao maio francês de 68 (MACEY, 1990; ERIBON, 1990). Impressionado pelas experiências políticas com as quais havia se deparado em sua estadia na Tunísia, nos mesmos meses dos levantes parisienses, Foucault teria se decepcionado com as manifestações francesas, em tudo distintas do vitalismo e da coragem física demonstrada pelos jovens tunisianos, também eles mobilizados pelo discurso de inspiração marxista, mas que o tomavam, antes de tudo, como uma "força moral" e por meio de uma significação existencial (FOUCAULT, 2001, p. 899-900). A atitude de Foucault seria transformada em pouco tempo, com a radicalização e disseminação dos conteúdos críticos em espaços até então preservados das contestações de 68, ainda que conservasse um "saudável desprezo" pelos grupos militantes franceses (WOLIN, 2010, p. 291). Ao contrário de Lacan e Guattari, 
Foucault nunca se envolveu doutrinariamente com esses grupos, seja para incorporá-los à sua organização, seja para discipliná-los em uma nova disposição normativa. A aproximação e, em algumas circunstâncias, a colaboração intensa foram estabelecidas enquanto alianças táticas e não a partir da concordância em torno de um mesmo projeto político. Isso explica a relação muito próxima firmada entre Foucault e os maoístas da Gauche Prolétarienne durante as atividades do GIP. Essa intervenção localizada e desprovida de pactuação em torno de ideais estáveis e universais definiria, segundo a própria leitura foucaultiana, o "intelectual específico" (FOUCAULT, 1996, p. 11). A nova figura do engajamento imporia, portanto, a regionalidade das lutas e do poder, cuja teoria não deveria ser alheia à prática das alianças pontuais com grupos ideologicamente heterogêneos. É sob essa concepção que o GIP ocupa, no pensamento de Foucault, um lugar diferencial, no qual, pela primeira e única vez, a instância conceitual de suas obras tanto incide quanto é sustentada pelo saber estratégico militante (MAUGER, 2000; PERROT, 1986).

Dessa perspectiva, a noção teórica de um poder multifacetado, ubíquo e "microfísico" não tem o valor de apanágio foucaultiano, sendo, antes, uma usual representação prática entre os militantes. Vocalizada durante a eclosão dos levantes de 68, ela dava forma interpretativa a uma profunda transformação das estruturas político-sociais. No entanto, o reconhecimento do caráter difuso da dominação não teria qualquer função estratégica sem uma demarcação do nível e intensidade do poder, o que só poderia ser medido pela conduta de enfrentamento militante. É na órbita dessa condicionalidade que o GIP exerce uma função singular. Impulsionado pelo espírito de disseminação das lutas, o GIP responde a essa necessidade de demarcação do poder (SALLE, 2004). Mesmo que Foucault tenha manifestado interesse e, em alguns casos, um certo fascínio por determinadas propostas de radicalização política - algumas defendendo o recurso à violência -, a ação direta, ao contrário do que ocorrera na EFP, não foi elevada a modelo organizacional no GIP. $\mathrm{Na}$ dinâmica deste dispositivo, a ação jamais seria direta, mediada que estava pela figuração do sujeito, o detento da prisão, portador de uma experiência imperceptível, para a qual era, portanto, preciso garantir visibilidade. Essa ação mediada pelo "outro" permitia uma disposição formal do sujeito e do poder, isto é, ela identificava, por intermédio de suas práticas militantes, a qualidade relacional e não substantiva da dominação, pressuposto das pesquisas genealógicas de Foucault. Desse modo, na condição de dispositivo de engajamento, o GIP forneceu, para a teoria foucaultiana, o princípio epistemológico de sua análise genealógica do poder.

A despeito da importância de melhor compreender o impacto do GIP sobre a obra de Foucault - uma questão que vem sendo trabalhada ${ }^{21}$ e que tem demandado um detalhamento mais fino das interações possíveis entre eles -, o aspecto teórico mais relevante colocado por essa disposição formal consiste na hipótese gipeana de uma metafísica do poder como postulado subjacente às instâncias reticulares e não-substantivas da dominação. Com o conceito de "corpo sem órgãos", Deleuze e Guattari (1972) construíram hipótese semelhante em $O$ Anti-édipo. Todavia, na versão gipeana essa metafísica não ganha estilo discursivo e tampouco se expressa pela teoria. Ela é composta por contrastes e confluências da prática militante, extração imaterial do encontro real com as formas excessivas de poder. A especificação das lutas, da qual o GIP é instrumento, dispõe formalmente a relação de dominação, mas não o pode fazer sem sua contraparte metafísica, a paradoxal postulação prática de uma substância do poder. É nesse aspecto que a regionalização, tomada politicamente para estender o domínio das lutas, compreende o pressuposto de uma metafísica. A relação entre GIP e o pensamento foucaultiano abre-se, assim, para uma outra ordem de problemas, muito além da simples representação crítica da relação entre teoria e prática. Por intermédio dos dispositivos intelectuais de engajamento, os sedimentos militantes e sua convergência estratégica na postulação prática de uma substância da dominação puderam ganhar forma e expor sua racionalidade. Se a presunção última do estruturalismo francês havia sido a existência de "uma ciência já escrita nas coisas" (MERLEAU-PONTY, 2008, p.191), nos dispositivos soixante-huitards são as "coisas" que já estão inscritas 
na "ciência". A regionalização de uma totalidade metafísica do poder designa, particularmente no GIP, a base de uma racionalidade prática que, entrecruzada com os vetores estratégicos da politização da subjetividade e do modelo organizacional da ação direta, objetiva formalmente sua militância. Fundamental convocar a memória e os enunciados dessa racionalidade, de perscrutar sua eficácia e de provê-la de consistência e originalidade teórica. Sob a sombra do marxismo crepuscular dos anos 1970, será ela a projetar os horizontes que marcam, ainda hoje, nossa atualidade política.

\section{NOTAS}

1. IMEC. Fonds Félix Guattari. GTR 54.17. Conclusions présentés par Pons (Lyon) et acceptées par délégués de la Gauche au VIII ${ }^{\text {ème }}$ Congrès de l'UEC, 7 mars 1965. Todas as traduções dos textos em língua estrangeira são de minha autoria e inteira responsabilidade.

2. Na acepção de Robert Castel, “o 'social' consiste em sistemas de regulações não mercantis, instituídas para tentar preencher esse espaço [entre a organização política e o sistema econômico].” (CASTEL, 1999, p. 31).

3. A despeito da crítica ao voluntarismo vanguardista embutido no dogma leninista, o documento permanece atrelado a ele: "É a própria consciência da classe operária que deve ser modificada em correlação com a condução, pelo partido de vanguarda, de uma política revolucionária, isto é, da criação de situações revolucionárias e da exploração coerente destas. Por conseguinte, algumas condições prévias deverão ser reunidas para que se possa criar um partido com essas características." (GUATTARI, 2004, p. 170)

\section{IMEC. Fonds Félix Guattari. GTR 53.4. L'O.G : documentation et correspondance.}

5. É certo que essa configuração do établissement foi praticada ao final de um processo de radicalização do maoísmo francês. Nos debates entre os estudantes da recém-criada (1966) Union des Jeunesses Communistes Marxistes-Léninistes (UJCML), dissidência da UEC e de cujo núcleo sairia a Gauche Prolétarienne, a sua defesa era feita contra a ideia "pequeno-burguesa" de "revolucionarização de si", enfatizando completamente a luta política como formação doutrinária e organização dos trabalhadores: "A linha pequeno-burguesa do terrorismo ideológico sobre os temas da revolucionarização de si deve ser criticada, combatida e desfeita. (...). É pelo trabalho político, a educação política, a luta prolongada no seio das massas que nossos camaradas poderão transformar profundamente seu ponto de vista e aprender a servir corretamente o povo, a fazer a revolução. Para quem é da crítica de nossa posição de classe, de nossa concepção de mundo, nada pode se substituir ao controle que exercem as próprias massas. No imediato, a arma dos militantes na luta ideológica no interior da organização é a discussão política apoiada, à luz do M.L. [Marxismo-leninismo], no pensamento de Mao." BDIC. Fonds Gauche Prolétarienne. F delta rés 576/3/2/1. Aux groupes d'établissement.

6. Sendo a Itália o exemplo mais significativo. Cf. CECI (2013); TARI (2011); GIACHETTI \& SCAVINO (2005); RICCIARDI (2012); PANVINI (2014); BIANCHI \& CAMINITI (2007).

7. Nesse momento de entrada e instalação das ideias maoístas na França, a única formulação de Althusser sobre a Revolução cultural chinesa foi apócrifa, publicada na revista do círculo marxista dos alunos da École Normale Supérieure, Cahiers Marxistes-Léninistes, em 1966: "O grande interesse político e teórico da R.C. [Revolução Cultural] é de constituir uma convocação solene da concepção marxista da luta de classes e da revolução. A questão da revolução socialista não é regulada definitivamente pela tomada de poder e a socialização dos meios de produção. A luta de classes continua sob o socialismo em um mundo submisso às ameaças do imperialismo. É então, antes de tudo, na ideologia que a luta de classes decide a sorte do socialismo: progresso ou regressão, via revolucionária ou via capitalista. As grandes lições da R.C. ultrapassam a China e outros países socialistas. Elas interessam a todo o movimento comunista internacional. Elas clamam que o marxismo não é nem uma religião da história, nem um evolucionismo, nem um economicismo. Elas clamam que o domínio da ideologia é um dos campos da luta de classes e que ele pode tornar-se o lugar estratégico em que, em determinadas circunstâncias, se joga a sorte da luta de classes. Elas clamam que existe um lugar extremamente profundo entre a concepção teórica do marxismo e a luta de classes ideológica. Elas clamam 
que toda grande revolução não pode ser senão a obra das massas, e que o papel dos dirigentes revolucionários é dar integralmente às massas os meios para se orientarem e se organizarem, lhes dando integralmente a bússola e a lei do marxismo-leninismo, de se colocar a formá-las para poder em seguida ajudá-las a exprimir sua vontade e resolver seus problemas. Não se trata de exportar a R.C. Ela pertence à Revolução chinesa. Mas suas lições teóricas e políticas pertencem a todos os comunistas. Essas lições, os comunistas devem tomá-las da R.C. e fazer delas o seu bem.” Texto publicado com o título « Sur la révolution culturelle » em Cahiers Marxistes-Léninistes n¹4, novembre 1966, p. 16.

8. “Após 1968, as coisas seriam revertidas: as forças sobre as quais Althusser havia primeiro podido se apoiar estavam essencialmente fora do P.C. Não era mais tanto o Partido que ele fez mover, mas os gauchistas. Tratava-se de reconduzir ao Partido uma certa franja do maoísmo. Também os textos de Althusser tornam-se voluntariamente contestatórios: reflexões amargas sobre as carências do Partido («À propos de l'article de Michel Verret »), zombaria quanto à sua política escolar («Idéologie et appareils idéologiques d'état »), versão não oficial do stalinismo (« Réponse à John Lewis »). São de agora em diante os gauchistas que são visados pela tática althusseriana. Dito de outro modo: é agora a heterodoxia que esconde a ortodoxia. E enquanto seus colegas batalham pela convocação da ciência contra a ideologia, Althusser põe em reserva a nova arma teórica que poderia selar a aliança dos intelectuais revisionistas avançados com a franja moderada dos intelectuais "gauchistas": a luta de classes na teoria." (RANCIÈRE, 2011, p. 132-133)

9. [E. Balibar]: "Althusser havia decidido - e é o que ele explica no primeiro desses cursos - que os cientistas eram espontaneamente materialistas e os filósofos espontaneamente idealistas. Consequentemente, a luta de classes na teoria se encontrava em certa medida encarnada, no interior da universidade, pela relação entre filósofos e literatos, de uma parte, e os cientistas, de outra. Isso reproduziria, em um outro jargão, coisas positivistas, pós-kantianas, que remontam (como Canguilhem indicava) até Comte etc. Como sempre, o aspecto pessoal interveio também: muitos de nossos amigos, de nossos camaradas comunistas, eram cientistas, sobretudo os físicos e os matemáticos. Eles estavam muito interessados pela filosofia, e nós tínhamos um tropismo pró-científico. Bom, Pierre Macherey teve sempre um grande talento pedagógico, tinha a paixão do ensino e ele procurava alunos. $\mathrm{O}$ ano em que nos conhecemos, ele me deu um curso privado, ninguém além de mim, na qual me explicou as Cinq Psychanalyses de Freud, seguido por um segundo, sobre o homem e o animal. E Pierre teve a ideia, depois de Lire le Capital, que seria necessário cursos de filosofia para os não-filósofos, era sua ideia. Em 1965-66, ele montou, uma vez por semana, um curso de iniciação, no qual recontava Descartes, Hegel etc.; o público era constituído por cientistas, pessoas como Savéant, minha esposa Françoise, que era física etc., e isso funcionava muito bem. Althusser achou que era uma ideia de gênio, que permitia misturar várias coisas ao mesmo tempo: de uma parte, a ideia de que havia questões filosóficas essenciais que se jogavam ao redor de certas rupturas ou revoluções epistemológicas nas ciências; de outra parte, a luta ideológica no domínio das ciências e ao redor das novas ciências." (BALIBAR \& DUROUX, 2012)

10. Cujo manuscrito e registros complementares serão publicados pela primeira vez apenas em 2014. Cf. ALTHUSSER (2014).

11. Em interpretação antípoda a esta, Ferry e Renault são autores do ensaio inaugural da crítica que atribui à "afirmação do Eu contra o sistema", suposto lema do "pensamento 68", os males do individualismo acirrado da década de 1980. (FERRY \& RENAULT, 1989, p.55).

12. A expressão, lembra Sommier (SOMMIER, 2008), foi utilizada por Louis Althusser para designar o mesmo fenômeno.

\section{A esse respeito, ver especialmente DRESSEN,1999.}

14. Talvez a exceção mais conhecida tenha sido a trajetória de radicalização política de Pierre Goldman. Trajetória estilizada em uma autobiografia de grande repercussão na França, sobretudo após seu assassinato, em 1979. Cf. GOLDMAN,1975.

15. Notadamente, os trabalhos de Bernard-Henri Lévy e André Glucksmann. 
16. Evidentemente, com isso não estamos propondo uma compreensão estanque dos dispositivos. Entre eles, uma inegável rede de transmissões conceituais e práticas, uma troca de saberes e influências recíprocas, como a que havia marcado a relação entre Foucault e o CERFI. Sobre esse ponto, ver MOZÈRE, 2004.

17. O grupo "Socialismo ou Barbárie” foi um dos precursores da defesa do modelo na França pós-segunda guerra. Para tomar conhecimento dos debates em torno do grupo, ver CASTORIADIS, 2012a; 2012b.

18. Ou, no âmbito da EFP, “transferência de trabalho”. Cf. LACAN, 2003.

19. Sobretudo no seminário de 1959-1960. Cf. LACAN, 2000.

20. A etificação da teoria também foi atribuída a Foucault, sobretudo a partir de seus últimos trabalhos, os dois volumes finais de A história da sexualidade e, mais recentemente, depois da publicação do curso de 1982-83 no Collège de France. Mas, ao contrário de Lacan, Foucault não se apoiou em qualquer dispositivo de engajamento, mesmo durante sua participação no GIP. Talvez isso explique a razão para que a etificação da teoria foucaultiana não seja um problema prático e, portanto, não tenha qualquer efetividade política direta. Para uma leitura que aproxima a teoria de Foucault com o seu posicionamento de militante, ver ARTIÈRES \& POTTE-BONNEVILLE, 2012; HARDT, 2010.

21. A respeito do impacto da radicalização política dos anos de 1970 sobre o pensamento de Foucault, muito além do contexto do GIP, ver HANNAH, 2012.

\section{REFERÊNCIAS BIBLIOGRÁFICAS}

ALTHUSSER, L. 2014. Initiation à la philosophie pour les non-philosophes, Paris : Puf. 1964. Problèmes étudiants, in : La Nouvelle critique, n¹52, janvier 1964. 1998. Solitude de Machiavel, Paris : Puf/Actuel Marx.

ANSART, P. 1983. La gestion des passions politiques, Paris : L’Age d'Homme.

ARTIÈRES, P. ; POTTE-BONNEVILLE. 2012. D'après Foucault: gestes, luttes, programmes, Paris: Éditions Points.

BALIBAR, E. ; DUROUX, Y. 2012. Une conjoncture philosophique: un entretien avec Étienne Balibar et Yves Duroux [traduzido como 'A Philosophical Conjuncture': An Interview with Étienne Balibar and Yves Duroux, na versão inglesa], in: HALLWARD, P. and PEDEN, K. (org.) Concept and Form, interviews and essays on The Cahiers pour l'analyse, v.2, London: Verso.

BIANCHI, S. ; CAMINITI, L. 2007. Gli autonomia. Le storie, le lotte, le teorie, 3 volumes, Roma : Derive Approdi.

BOURDIEU, P. 1998. Gênese e estrutura do campo religioso, in: A economia das trocas simbólicas, São Paulo: Ed. Perspectiva.

CASTEL, R. 1999. As metamorfoses da questão social: uma crônica do salário, Rio de Janeiro: Ed. Vozes.

CASTORIADIS, C. 2012a. L'Expérience du mouvement ouvrier, I, in: La Question du mouvement ouvrier tome 1, Paris : éditions du Sandre. 
2012b. L'Expérience du mouvement ouvrier, II, in: La Question du mouvement ouvrier tome 2, Paris: éditions du Sandre.

CECI, G. M. 2013. Il terrorismo italiano. Storia di un dibattio, Roma: Carocci editore.

CHRISTOFFERSON, M. S. 2004. French intellectuals against the left: the antitotalitarian moment of the 1970s, New York: Berghan Books.

DAMAMME, D. et al. 2008. Mai-Juin 68, Paris: Les éditions de l'Atelier.

DARDOT, P. ; LAVAL, C. 2009. La nouvelle raison du monde, essai sur la société néolibérale, Paris : La Découverte.

DEBORD, G. 1995. 1968, in: Oeuvres, Paris: Gallimard.

DELEUZE, G. 1977. Différence et répétition, Paris: Puf.

DELEUZE, G. ; GUATTARI, F. 1972. L’Anti-OEdipe, Paris: Les Éditions de Minuit.

DONZELOT, J. 1994. L'invention du social - Essai sur le déclin des passions politiques, Paris: Éditions du Seuil.

EWALD, F. 1984. L' État Providence, Paris: Bernard Grasset.

ERIBON, D. 1990. Michel Foucault, São Paulo: Companhia das Letras. DOSSE, F. 2007. Gilles Deleuze et Félix Guattari, biographie croisée, Paris: Éditions La Découverte. DRESSEN, M. 1999. De l'amphi à l'établi. Les étudiants maoistes à l’usine (1967-1989), Paris: Éditions Belin.

ERIBON, D. 1990. Michel Foucault - Uma biografia por Didier Eribon, São Paulo: Companhia das Letras. FERRY, L.; RENAULT, A. 1989. Pensamento 68: ensaio sobre o anti-humanismo contemporâneo, São Paulo: Ensaio.

FOUCAULT, M. 1996. .Microfísica do poder, Rio de Janeiro: ed. Graal. 2001. Interview avec Michel Foucault, in : Dits et Écrits I (1954 - 1975), Paris: Quarto/Gallimard. .2001. Entretien avec Michel Foucault, in: Dits et écrits II (1976-1988), Paris: Quarto/Gallimard.

FOURQUET, F. 1982. L'accumulation du pouvoir. Ou le désir d'État, Paris: Recherches no 46.

GAULEJAC, V. 1987. La nevrose de classe, Paris: H\&G editeurs.

GIACHETTI, D. ; SCAVINO, M. 2005. La Fiat aux mains des ouvriers. L'automne chaud de 1969 à Turin, Paris: Les nuits rouges éditions.

GOLDMAN, P. 1975. Souvernirs obscurs d’un juif polonais né en France, Paris: Points.

GUATTARI, F. 2004. Psicanálise e transversalidade. Ensaios de análise institucional, Aparecida: Editora Ideias \& Letras. 
.2012. De Leros à La Borde, Paris: Nouvelles Éditions Lignes.

HANNAH, M. G. 2012. Foucault's "German moment": genealogy of a disjuncture, in: Foucault Studies, no13, pp.116-137, mar 2012, p. 85 - 107.

HARDT, M. 2010. Militant life, New Left Review, 64, July Aug 2010, p. 151-160.

KATSIAFICAS, G. 2006. The Subversion of Politics: European Autonomous Social Movements and the Decolonization of Everyday Life, Oakland: AK Press.

LACAN. J. 1999. O seminário 17: o avesso da psicanálise, Rio de Janeiro: Zahar editor. 2000. O seminário, livro 7: A ética da psicanálise, Rio de Janeiro: Zahar editor. .2003. Proposição de 9 de outubro de 1967 sobre o psicanalista de Escola, In: Outros Escritos, Rio de Janeiro: Zahar. .2008. O seminário 16: De um Outro ao outro, Rio de Janeiro: Zahar Editor.

MACEY, D. 1993. The lives of Michel Foucault, New York: Vintage books.

MANDOUÉ, R. 2009. Nouveaux philosophes et antimarxisme, Paris: L'Harmattan.

MANIGLIER, P. (dir.). 2011. Le moment philosophique des années 1960 en France, Paris: Puf.

MATONTI, F. 2005. La politisation du structuralisme. Une crise dans la théorie, in : Raisons Politiques, $2005 / 2, n^{\circ} 18$, p. 49-71.

2009. Marx entre communisme et structuralisme, in : Actuel Marx, 2009/1, n 45, p. 120-127.

MAUGER, G. 2000. Un marchand d'instruments politiques: à propos de Michel Foucault, In: Lire les Sciences Sociales, vol.3, 1994-1996, Paris: Hermes Science Publications.

MAUPEOU-ABBOUD, N. de. 1974. Ouverture du ghetto étudiant. La gauche étudiante à la recherche d'un nouveau mode d'intervention politique (1960-1970), Paris: Éditions Anthropos.

MERLEAU-PONTY, M. 2008. Signes, Paris: Gallimard/Folio.

MORIN, E. ; LEFORT, C. ; CASTORIADIS, C. 2008. Mai 68, La brèche, suivi de Vingt ans après, Paris: Fayard.

MOZÈRE, L. 1992. Le Printemps des crèches. Histoire et analyse d'un mouvement, Paris: L'Harmattan. .2004. Foucault et le CERFI: instantanés et actuallité, In: La Portique, nº13-14, p. 2-9.

PANVINI, G. 2014. Cattolici e violenza politica. L'altro álbum di famiglia del terrorismo italiano, Venezia: Marsilio Editori.

PERROT, M. 1986. Le leçon des ténèbres: Michel Foucault et la prison, In: Actes, nº54. 
PROCACCI, G. 1999. Gouverner la misère, Paris: Ed. Seuil.

RANCIÈRE, J. 2011. La leçon d'Althusser, Paris: La Fabrique éditions.

2012. Que sous forme de la rupture: un entretien avec Jacques Rancière, [traduzido como Only in the form of rupture : an interview with Jacques Rancière, na versão inglesa], in : HALLWARD, P. and PEDEN, K. (org.) Concept and Form, interviews and essays on The Cahiers pour l'analyse, v.2, London: Verso.

RICCIARDI, S. M. 2012. Scene di rivolta e autorganizzacione di classe in Italia (1960-1980), Roma: Derive Approdi.

ROUDINESCO, E. 1986. História da psicanálise na França: a batalha dos cem anos, v.2: 1925-1985, Rio de Janeiro: Jorge Zahar.

SALLE, G. 2004. Mettre la prison à l'éprouve. Le GIP en guerre contre l'intolérable", In: Cultures \& Conflits, no55, p. 2-17.

SAPIRO, G. 2009. Modèles d'intervention politique des intellectuels. Le cas français, in : Actes de la Recherche en Sciences Sociales, 2009/1, numéro 176-177, p. 8-31.

SCHNAPP, A.; VIDAL-NAQUET, P. 1988. Journal de la commune étudiante, textes et documents. Novembre 1967 - juin 1968, Paris: Éditions du Seuil.

SIBERTIN-BLANC, G. 2014. Préface, in : ALTHUSSER, L. Initiation à la Philosophie pour les non-philosophes, Paris: Puf.

SMITH, J. ; MONCOURT, A. 2009. The Red Army Faction: a documentary history, volume 1, projectiles for the people, Montreal: Kersoledeb Publishing.

SOMMIER, I. 2008. La violence politique et son deuil l'après 68 en France et en Italie, Paris: Presses Universitaires de Rennes.

TARI, M. 2011. Autonomie! Italie, les années 1970, Paris: La Fabrique éditions.

VANDENBERGHE, F. 2008. Deleuzian capitalism, in: Philosophy Social Criticism, v.34, n.8, Los Angeles, London, New Delhi and Singapore: Sage Publications, p.877-903.

WOLIN, R. 2010. The wind from the west: french intellectuals, the cultural revolution, and the legacy of the 1960s, New Jersey: Princeton University Press.

\section{ARQUIVOS}

BIBLIOTHÈQUE DE DOCUMENTATION INTERNATIONALE CONTEMPORAINE (BDIC). Fonds Gauche Prolétarienne.

INSTITUT MÉMOIRES DE L'ÉDITION CONTEMPORAINE (IMEC). Fonds Félix Guattari. 